\title{
Problems of improving the quality of life of miners in mining regions on the example of the Kemerovo region (Kuzbass) and ways to solve them
}

\author{
Veronika Batievsky ${ }^{1}$, Mikhail Sokolovsky ${ }^{1}$ and Elena Moroz $^{2}$ \\ ${ }^{1}$ Kemerovo State Medical University, Kemerovo Region, 650056, 22A, Voroshilova str., Kemerovo, \\ Russia. \\ ${ }^{2}$ Siberian Federal University, 660041, 79, Svobodny pr., Krasnoyarsk, Russia.
}

\begin{abstract}
The quality of life is an integral indicator that includes the following indicators: the level of health of the population, education, employment, poverty, spending and consumption, life expectancy at birth, and so on. There are economic, social, ecological and climatic, political and cultural criteria for the quality of life. The problem of ensuring the proper level and quality of life of miners in mining regions is considered on the example of the Kemerovo region (Kuzbass). Unfavorable production factors in coal mining include meteorological conditions, pollution of the mine atmosphere with harmful gases, the release of coal dust during any technological processes, dust formation, lack of sunlight, noise and vibration, high risk of injury; difficult water supply and sanitation. These factors contribute to the formation of occupational diseases, which leads to a decrease in the quality of life. It is necessary to develop a set of measures to eliminate the identified problems: structural changes in the industry, the development of coal-technical, coal-chemical and energy-coal clusters, improving the consumer properties of coal products to expand sales markets, the formation of new professional standards and improving the system of training and advanced training of personnel, the introduction of unified systems of industrial and environmental safety.
\end{abstract}

\section{Introduction}

The present study is carried out on an actual topic, since long-term statistical observations record the highest occupational morbidity in the Kemerovo region in comparison with the data for the Russian Federation as a whole. The number of deaths and victims of industrial injuries in Kuzbass also consistently exceeds the national figures [1]. The deterioration of the health of miners, the increase in general and occupational morbidity inevitably leads to a decrease in their quality of life, to a deterioration in the qualitative and quantitative characteristics of the labor force. To solve these problems, it is necessary to develop a set of social, economic and institutional measures. 
Environmental aspects are becoming extremely relevant in the functioning of mining regions. At the initiative of the Governor of the Kemerovo Region, the regional integrated project "Clean coal-clean Kuzbass" was launched in March 2019, the task of which is to restore order in the coal enterprises of the region, to provide measures to protect the territories from heavy trucks transporting coal. At the same time, the environmental component should become the basis for the development of industry, in particular, coal [2].

\section{Results and Discussion}

The quality of life is an integral indicator that includes the following indicators: the level of health of the population, education, employment, poverty, spending and consumption, life expectancy at birth, and so on [3]. When analyzing the level and quality of life, two approaches are used:

1. Assessment of the system of indicators at the population level (for example, the state of public health, GNP per capita).

2. A composite index of the level and quality of life based on individual indicators (for example, the state of health of an individual, his personal disposable income).

The criteria can also be divided into:

- economic,

- social,

- ecological and climatic conditions,

- political and cultural.

Economic measures of quality of life. Among the most obvious economic indicators of the level and quality of life, researchers include:

- gross national product per capita;

- individual income level (personal disposable income);

- distribution of income in society (Gini index, Lorentz coefficient, decile coefficient of income differentiation);

- the level of consumption of various material goods and services by class of goods; the level of employment and other;

- the level of employment and unemployment [4].

Social measures of quality of life. Studying such a phenomenon as social trust, some sociologists and economists define it as one of the factors of quality of life. The topic of social and institutional trust becomes especially relevant in connection with the development of formal norms and rules of the modern information society [5]. Some researchers refer to the social criteria:

- accessibility of educational services and cultural values;

- degree of personal safety assurance;

- justice and the rule of law.

Ecological and climatic indicators of quality of life:

- state of the environment

- environmental safety

- power consumption level

There are a number of studies to identify the relationship between the parameters of quality of life, energy consumption and environmental safety. They argue that uncontrolled energy consumption, especially from non-renewable sources, creates an excessive burden on the environment and threatens to increase social inequality both within and between countries [6].

Political and cultural factors of quality of life. For example, when studying the factors that affect the quality of life of the population, it was statistically reliably proved that the state management of the development of health, education, ecology, and security correlates 
with the natural growth of the population, with satisfaction and the level of perception of happiness [7]. The authors also consider the development of democratic institutions to be important political factors.

Let's consider the problem of ensuring the proper level and quality of life of miners in mining regions on the example of the Kemerovo region (Kuzbass). Let's describe the state of the coal industry in Russia and Kuzbass. According to the central dispatching Department of the Fuel and Energy complex (CDU "TEK"), as of January 01, 2021, coal production in the Russian Federation was carried out by 179 coal enterprises, including 58 mines and 121 open-pit mines. The production capacity for coal production at the beginning of 2020 was 508 million tons.

The Kemerovo Region (Kuzbass) is located in the south of Western Siberia and was formed by the Decree of the Presidium of the Supreme Soviet of the USSR of January 26, 1943 "On the formation of the Kemerovo Region as part of the RSFSR". The gross regional product in 2020 amounted to 1,110. 4 billion rubles. The share of Kuzbass in Russia's export supplies of coal is $90 \%$. The sectoral structure of the economy of Kuzbass is as follows: mining $42.10 \%$; manufacturing $14.00 \%$; agriculture $2.20 \%$; construction $5.40 \%$; wholesale and retail trade $26.30 \%$; other $10.00 \%$ [ 8 .

The dynamics of the main indicators of socio-economic development of the region is reflected in the table [9].

Table 1. Dynamics of the main indicators of socio-economic development of the Kemerovo Region for the period 2018-2020.

\begin{tabular}{|c|c|c|c|c|c|}
\hline \multirow{2}{*}{ Indicator } & \multicolumn{5}{|c|}{ Years } \\
\cline { 2 - 6 } & $\mathbf{2 0 1 8}$ & \multicolumn{2}{|c|}{$\mathbf{2 0 1 9}$} & \multicolumn{2}{c|}{$\mathbf{2 0 2 0}$} \\
\cline { 2 - 6 } & absolute & absolute & $\begin{array}{l}\text { growth } \\
\text { rate, } \%\end{array}$ & absolute & $\begin{array}{c}\text { growth } \\
\text { rate, } \%\end{array}$ \\
\hline $\begin{array}{c}\text { Gross regional product } \\
\text { in current prices } \\
\text { million rubles }\end{array}$ & 1058430.40 & 1266424.50 & 119.65 & 1110415.10 & 87.68 \\
\hline $\begin{array}{c}\text { Average annual } \\
\text { population, people }\end{array}$ & 2684566 & 2666055 & 99.31 & 2645650 & 99.23 \\
\hline $\begin{array}{c}\text { Housing } \\
\text { commissioning, } \\
\text { thousand sq. m }\end{array}$ & 639.80 & 765.80 & 119.69 & 824.50 & 107.67 \\
\hline $\begin{array}{c}\text { Agricultural products, } \\
\text { billion rubles }\end{array}$ & 46.90 & 47.80 & 101.92 & 52.80 & 110.46 \\
\hline $\begin{array}{c}\text { Net financial result of } \\
\text { enterprises, mln. } \\
\text { rubles }\end{array}$ & 257398.00 & 249191.00 & 96.81 & 116825.00 & 46.88 \\
\hline $\begin{array}{c}\text { Labor force, thousand } \\
\text { people }\end{array}$ & 1276.10 & 1271.80 & 99.66 & 1275.88 & 10.04 \\
\hline $\begin{array}{c}\text { Investments in fixed } \\
\text { assets billion rubles }\end{array}$ & 248.70 & 288.40 & 115.96 & 276.70 & 95.94 \\
\hline
\end{tabular}




\begin{tabular}{|c|c|c|c|c|c|}
$\begin{array}{c}\text { Foreign trade turnover } \\
\text { exports, mln. USD }\end{array}$ & 16444.70 & 14888.60 & 90.54 & 11624.80 & 78.08 \\
\hline $\begin{array}{c}\text { Foreign trade turnover } \\
\text { import, mln USD }\end{array}$ & 892.30 & 865.10 & 96.95 & 789.90 & 91.31 \\
\hline
\end{tabular}

\section{Results}

Consider the environmental harm of coal mining and the mechanism of formation of occupational diseases. It is known that mining can be carried out in an open and underground way. The open-pit mining method is carried out using open-pit mine workings (sections, quarries, mines) that have an open-loop cross-section. In the underground mining method, minerals are extracted from the subsurface through the construction of special underground workings-mines. A mine is an independent production unit that is part of a mining enterprise (mine).

Open-pit coal mining has a greater negative environmental impact on the environment than underground mining. This is due to the greater amount of radioactive elements, toxic and heavy metals, salts and oxides in the displaced host rocks. In addition, the area of disturbed land increases, the pollution of the atmosphere with coal and rock dust, exhaust gases increases, and the noise level increases. When performing open-pit mining operations, the following harmful production factors prevail: increased noise and vibration levels, infrasound, air pollution with coal dust and aerosols, unfavorable operating conditions that violate the dose-time parameters of labor protection. In addition, the ergonomic machine-man model in the workplace of a bulldozer driver, excavator, drilling machine, and driver of technological transport carries a large range of adverse effects [10].

Unfavorable production factors in coal mining are as follows:

- unfavorable weather conditions (in the mines of Kuzbass, the air temperature in the faces is $12-15{ }^{\circ} \mathrm{C} 0$ in summer, and $7-11^{\circ} \mathrm{C} 0$ in winter);

- pollution of the mine atmosphere with harmful gases (carbon dioxide, methane, hydrogen sulfide, sulfur dioxide, carbon monoxide);

- the release of coal dust in the implementation of any technological processes (dust formation accompanies all the main processes of coal mining: cutting, breaking and loading, transportation, etc.);

- no sunlight;

- noise and vibration (vibroacoustic factors);

- high injury risk;

- difficult water supply and sanitation [11].

These factors, both in open-pit and underground mining, contribute to the formation of professionally-caused chronic non-specific lung diseases, pneumoconiosis, colds, sensorineural hearing loss, pustular skin diseases, myositis, neuritis of various localization, radiculopathy In sections where there is an increased concentration of methane and other hydrocarbons in the air, there are shifts in the function of the autonomic nervous system. The deterioration of the health of miners, the increase in general and occupational morbidity inevitably leads to a decrease in their quality of life (the problem of the individual and the population) and to a deterioration in the qualitative and quantitative characteristics of labor resources (the problem of the region and the state). Accordingly, it is necessary to develop a set of measures to eliminate the identified problems.

1. Continuation of structural changes: phased decommissioning of inefficient capacities with low labor productivity. 
2. Further development of coal-technical, coal-chemical and energy-coal clusters, which allow complex use of the capabilities of coal deposits [12].

3 . Improving the consumer properties of coal products to expand sales markets.

4. Formation of new professional standards, improvement of the system of training and advanced training of personnel.

5. Introduction of unified industrial and environmental safety systems [13].

\section{Conclusion}

Quality of life is an aggregated indicator that includes economic, social, environmental, climatic, political, and cultural indicators. The problem of ensuring the proper level and quality of life of miners in mining regions (for example, in Kuzbass) is caused by a number of harmful production factors inherent in both open and underground mining methods.

The impact of these factors contributes to the formation of occupational diseases. The deterioration of the health of miners, the increase in morbidity inevitably leads to a decrease in their quality of life.

To solve these problems, further structural transformations, the development of target clusters, the improvement of consumer properties of products, a projective personnel policy, and the development of unified systems of industrial and environmental safety are necessary.

\section{References}

1. V. Batievskaya, Occupational medicine and industrial ecology, 4, 242-247 (2019). https://doi.org/10.31089/1026-9428-2019-59-4-242-247

2. I. Kudryashova, M. Venger, N. Zakharova, E3S Web Conf. 105, 02005 (2019)

3. L. Kilimova, O. Lysikova, Ekonomichny chasopis-XXI, 179, 10, (2019)

4. E.R. Bouka, Components of Scientific and Technological Progress, 1(43), 13-16 (2020)

5. J.P. Bayer, Administrative consulting, 6(138), 136-140 (2020). DOI: 10.22394/17261139-2020-6-136-140.

6. O. Makarova, T. Kalashnikova, I. Novak, Ekonomichny chasopis-XXI, 184, 29-37 (2020). DOI 10.21003/ea.V184-03

7. A. Rakhmetova, Ye. Budeshov, Ekonomichny chasopis-XXI, 184, 133-153 (2020). DOI 10.21003/ea.V184-12

8. Official website of the Administration of the Government of Kuzbass. URL: https // ako.ru/upload/medialibrary

9. The official website of the Territorial Body of the Federal State Statistics Service for the Kemerovo Region - Kuzbass. URL: https://kemerovostat.gks.ru/municipal_statistics

10. I. Kudryashova, N. Zakharova, E. Kharlampenkov, E3S Web Conf. 21, 02016 (2017)

11. V. Batievskaya, Forms and methods of social work in various spheres of life (East Siberian State University of Technologies and Management, Ulan-Ude, 2018)

12. Batievskaya, Organism and living environment (Kemerovo, 2018).

13. Program for the development of the coal industry in Russia for the period up to 2035. Approved by the Order of the Government of the Russian Federation dated June 13, 2020 No. 1582-r (Ministry of Energy of the Russian Federation, Moscow, 2020) 